\title{
Academic Supervision: Efforts to Improve Teacher Quality in Developing the Professional Ability Educators
}

\author{
Silviany Rizkillah* \\ Education Administration Program \\ Universitas Pendidikan Indonesia \\ Bandung, Indonesia \\ *silvianyramram@gmail.com
}

\author{
Taufani Chusnul Kurniatun \\ Universitas Pendidikan Indonesia \\ Bandung, Indonesia
}

\begin{abstract}
The purpose of this study was to determine the benefits of academic supervision for teachers in SDN 263 Rancaloa in developing learning and teaching situations in class, the ability to diagnose student difficulties in learning, creativity in developing learning methods, creativity in planning, implementing, and evaluating internal learning, develop professionalism as a teacher. The research method used is a qualitative description, that is, the researcher will describe the situation experienced by teachers after carrying out supervision activities. Research respondents were teachers in SDN 263 Rancaloa. The techniques used were interviews, observation, and Group Discussion forums. Researchers conducted interviews with respondents with the aim of obtaining real information on the benefits of supervision activities, while in observation the researchers conducted a survey of teachers in SDN 263 Rancaloa, and were also directly involved in discussions. The results showed that supervision in SDN 263 Rancaloa could increase the professionalism of a teacher.
\end{abstract}

Keywords—teacher quality, professional, supervision

\section{INTRODUCTION}

Supervision is a coaching activity and activities carried out by a professional to assist teachers and other education personnel in improving teaching materials, methods and evaluation by continuously stimulating, coordinating and guiding teachers to become more professional in increasing the achievement of school goals. Supervision activities aim to improve teaching and learning processes and outcomes. Its main activity is to help teachers, but in its broad context it concerns other components of the school because teachers are also related to components of administration, facilities, school environment, and others. However, in its implementation, supervision activities have not been able to provide a sustainable contribution in improving the quality of teachers in teaching.

The reason for the unsuccessfulness of supervision activities in the school environment is not because of the program, the supervision technique that has been scheduled, but the follow-up of the supervision activities that are not running well due to the busy official activities of the principal and school activities so that the follow-up of the supervision activities is neglected. While supervision activities are activities that must be carried out continuously, as revealed by Sagala in Dalawi [1], supervision is professional assistance and guidance for teachers in carrying out instructional tasks to improve learning and teaching by continuously stimulating, coordinating and guiding to increase teacher position growth. individually or in groups. Supervision is a process for implementing what work has been carried out, evaluating it and if necessary correcting it so that the implementation of the work is in accordance with the original plan. Supervision is an effort to provide services so that teachers become more professional in carrying out their duties to serve students, (1) because the internal factors of the teacher and the internal school itself will cause supervision activities to not function to improve teacher quality. As it is known, teachers are the key to the presence of good quality in the field of education.

According to Manullang [2], supervision is a process for implementing any work that has been implemented, evaluate it and if necessary correct it with the intention that execution of work in accordance with the original plan. Supervision is an effort provide services so that teachers become more professional in carrying out their duties serve students.

Juridically, the issue of education supervision has received adequate and proportional attention by the government, this is based on the understanding of the importance of education supervision in the implementation of education in schools in the context of effectiveness and efficiency for achieving educational goals. As a concrete form of government attention to the issue of education supervision, the Education Management Standards by Primary and Secondary Education Units. In the Permendiknas [3], it is stated in letter C. Supervision and Evaluation, at number 1. The supervision program, point $\mathrm{f}$ states that the supervision of academic management is carried out regularly and continuously by the 
Principal of Schools / Madrasahs and school / madrasah supervisors.

Permendiknas [4], namely Permendiknas Number 41 of 2007 concerning Process Standards for Primary and Secondary Education Units, it also confirms the existence of supervision in schools as stated in V. Supervision of the Learning Process, Letter B. Supervision states: 1. Supervision of the learning process is carried out at the planning stage, implementation, and assessment of learning outcomes. 2. Supervision of learning is carried out by giving examples, discussions, training, and consultations. 3. Supervision activities are carried out by the head and supervisor of the education unit. From here it is clear that there is no single implementation process apart from educational supervision activities, in other words, both theoretically and juridically, the issue of education supervision occupies a strategic position in efforts to improve the quality of education. Wiles in Messi [5] has briefly formulated that supervision as an aid to teaching and learning situations is better. Adam and Dickey in Messi [5] define supervision as a service, especially regarding improvements in teaching and learning.

The purpose of supervision is to provide technical assistance and guidance to teachers (and other school staff) so that these personnel are able to improve the quality of their performance, especially in carrying out tasks, namely carrying out the learning process. In accordance with what Burtton said in Dalawi [1], "Supervision a Social Process", as follows: "Supervision is an expert technical service primarily aimed at studying and improving cooperatively all factors which affect child growth and development". In accordance with Burton's formulation, then: 1) Good supervision directs his attention to the basics of education and ways of learning and their development in achieving general educational goals. 2) The purpose of supervision is the improvement and development of the teaching-learning process in total; This means that the purpose of supervision is not only to improve the quality of teaching of teachers, but also to foster the growth of the teaching profession in a broad sense, including the provision of facilities that support the smoothness of the teaching and learning process, improving the quality of knowledge and skills.

Suharsimi Arikunto [6] expressed the purpose of supervision, namely providing assistance technical assistance and guidance to teachers (other school staff) so that these personnel are capable improve the quality of its performance, especially in carrying out tasks, namely carrying out learning process. If the quality of teacher and staff performance has improved, then quality learning will increase. Providing assistance and guidance can directly or indirectly to the teacher concerned".

\section{RESEARCH METHODS}

This research is a qualitative descriptive study, in the form of analysis of supervision activities in improving teacher quality in the form of creativity in planning, coaching and evaluating in learning and developing teacher professionalism.

The reason for choosing a qualitative descriptive approach in this study was because the researcher wanted to get a deep understanding of the benefits of supervision activities as a form of creativity and increased professionalism of teachers at SDN 263 Rancaloa.

The research method used in this research is descriptive method which aims to describe the research results by describing in detail, complete and in-depth the results of interviews, observations, and discussion forums from teachers of SDN 263 Rancaloa. This is done to obtain data that can be fully described in order to examine the function of supervision activities in improving teacher quality, namely creativity planning, coaching, and evaluating in learning and developing teacher professionalism, to support the data requirements the researcher will interview 10 teachers at SDN 263 Rancaloa people. teachers as supporting information to support this research. The data collection techniques used were interviews, observation.

In order to collect and collect the required research data as well as guidelines / data instruments used by involving data sources in this study, in more detail can be seen in the table below.

\section{A. Academic Supervision Questionnaire}

TABLE I. THE EFFECT OF ANALYSIS ON TEACHERS

\begin{tabular}{|c|c|c|c|}
\hline No & Questions & Yes & No \\
\hline 1 & $\begin{array}{l}\text { I have a lesson plan that was developed based on the } \\
\text { results of the syllabus study }\end{array}$ & & \\
\hline 2 & $\begin{array}{l}\text { I made the elements contained in the lesson plan } \\
\text { (opening, core activity, and closing) in detail }\end{array}$ & & \\
\hline 3 & I analyze students' abilities before making lesson plans & & \\
\hline 4 & $\begin{array}{l}\text { Before developing learning materials, I first identified } \\
\text { the learning ability needs of students. }\end{array}$ & & \\
\hline 5 & $\begin{array}{l}\text { I designed the development of teaching materials } \\
\text { according to the latest books according to the } \\
\text { applicable curriculum }\end{array}$ & & \\
\hline 6 & $\begin{array}{l}\text { I write down the events that occur during the learning } \\
\text { process in a journal }\end{array}$ & & \\
\hline 7 & $\begin{array}{l}\text { I can fully implement the learning scenario listed in } \\
\text { the lesson plan }\end{array}$ & & \\
\hline 8 & $\begin{array}{l}\text { To build a sense of pleasure and comfort in students I } \\
\text { manage a conducive learning process }\end{array}$ & & \\
\hline 9 & $\begin{array}{l}\text { To increase students' enthusiasm for learning I use a } \\
\text { variety of media }\end{array}$ & & \\
\hline 10 & $\begin{array}{l}\text { To help students understand the learning material I } \\
\text { made my own teaching aids. }\end{array}$ & & \\
\hline 11 & I give students the opportunity to ask questions. & & \\
\hline 12 & I help students who have learning difficulties & & \\
\hline 13 & I have notes about each student in the journal & & \\
\hline
\end{tabular}

\section{B. Student Learning Interest Questionnaire}

This questionnaire is to obtain suggestions or opinions regarding the learning that is being carried out and used as a basis for improvement in subsequent learning. 
TABLE II. THE EFFECT OF SUPERVISION ON STUDENT LEARNING

\begin{tabular}{|c|c|c|c|}
\hline No & Question & Yes & No \\
\hline 1 & $\begin{array}{l}\text { The learning material is accompanied by easy to } \\
\text { understand practice }\end{array}$ & & \\
\hline 2 & Learning accompanied by practice is not fun & & \\
\hline 3 & $\begin{array}{l}\text { If there are things that are unclear and students } \\
\text { ask questions, the teacher answers until they } \\
\text { understand them }\end{array}$ & & \\
\hline 4 & $\begin{array}{l}\text { Do a group assignment and you don't try to } \\
\text { understand it. }\end{array}$ & & \\
\hline 5 & $\begin{array}{l}\text { Study every day, even if there are no } \\
\text { assignments from the teacher or no teacher }\end{array}$ & & \\
\hline 6 & $\begin{array}{l}\text { Learning accompanied by practice can add } \\
\text { learning tools. }\end{array}$ & & \\
\hline 7 & If given a task you do not do it seriously & & \\
\hline 8 & $\begin{array}{l}\text { With learning accompanied by your practice, you } \\
\text { become active in participating in learning }\end{array}$ & & \\
\hline 9 & Fun learning atmosphere & & \\
\hline 10 & $\begin{array}{l}\text { Many get the opportunity to talk, express } \\
\text { opinions or ask questions from teachers or } \\
\text { friends }\end{array}$ & & \\
\hline 11 & $\begin{array}{l}\text { Many new and fun things that I have never } \\
\text { experienced or rarely experienced in previous } \\
\text { classes. }\end{array}$ & & \\
\hline 12 & Do students want learning to be done in class & & \\
\hline 13 & $\begin{array}{l}\text { Does the given learning method increase the } \\
\text { frequency of student learning }\end{array}$ & & \\
\hline 14 & Is the learning material given valuable question & & \\
\hline 15 & $\begin{array}{l}\text { The learning material is accompanied by easy to } \\
\text { understand practice }\end{array}$ & & \\
\hline
\end{tabular}

The data source triangulation technique is intended in this study so that in data collection researchers use multiple data sources, namely by using data sources in the form of information obtained through observations with teachers and students at SDN 263 Rancaloa, events that occurred at SDN 263 Rancaloa. which is obtained through observations of activities carried out by students and teachers and information through other supporting documents. Data analysis was carried out in several stages, namely: organizing the data, describing it into units, synthesizing it, arranging it into patterns, and making conclusions that can be shared with others. Because processing and analyzing data is an attempt to organize data systematically.

\section{RESULTS AND DISCUSSION}

In this study, the researcher asked 10 respondents to measure the usefulness of supervision in developing the quality of teachers in learning and teaching activities in the classroom. In this study, researchers also obtained results that will be discussed in four main points, namely that supervision can improve quality in:

- Develop learning and teaching situations in the classroom.

- Ability to diagnose student difficulties in learning.

- Creativity in developing learning methods.

- Creativity in planning, implementing, and evaluating learning in developing professionalism as a teacher.

\section{A. Develop Learning and Teaching Situations in the Classroom}

Based on interviews, supervision activities can develop learning and teaching situations in the classroom because the teaching and learning process is an educational interaction carried out by teachers and students in certain situations. Teaching or more specifically carrying out the teachinglearning process is not an easy job and can just happen. With the supervision of teachers in SDN 263 Rancaloa, they explore their potential by trying to develop teaching and learning situations in the classroom.

After interviewing students at SDN 263 Rancaloa, they said that the class atmosphere became crowded, I was not ashamed to go to the front of the class, I understood the addition of integers with story problems. According to the homeroom teacher of grade $6 \mathrm{C}$, Mrs. Resti, said that she tried to make students understand integers by finding the answers themselves by practicing in the school yard, the child seemed active and wanted to try. After practice, students are given questions about integers, no child gets a score under 5 .

Based on the results of research on ten respondents related to developing learning situations in the classroom, teachers in SDN 263 Rancaloa can improve the quality of their profession as teachers because they are forced to explore interactive and fun learning models, meaning that teachers are given the freedom to choose models that are considered to be fun, effective, interactive according to basic competencies. It does not have to refer to the learning model that has been listed in the teacher's handbook. Efforts in developing learning situations based on interviews, teachers in SDN 263 Rancaloa are conducting peer tutors, reviewing training results, looking for learning models on the internet. The aim is to create learning conditions that are pleasant for students, successful, on target, in accordance with existing competency standards, in addition to getting a satisfactory re-view from the supervisor.

Learning conditions or learning situations are conditions in which knowledge and experience activities occur through various mental processing processes. Meanwhile, according to Gagne, states in Azizah [7] "The assurance of learning is inferred from a difference in human being's performance before and after being placed in a learning situation. It means that a learning condition is a learning situation that can result in a change in behavior (performance) in a person after he is placed in that situation. Of course, it can be understood that learning conditions are a condition that affects the process and good learning outcomes, and vice versa.

The definition of learning according to Hamalik in Nurrita [8] is a modification or reinforcing behavior through experience (learning is defined as the modification or strengthening of behavior through experiencing). According to this understanding, learning is a process, an activity and not an outcome or goal. Learning is not just remembering, but it is broader than that, namely experiencing. Learning outcomes are not a mastery of training results but a change in behavior. 
Aunurrahman [9] states that learning is a process carried out by individuals to obtain a whole new change in behavior, as a result of the individual's own experience in interaction with his environment. According to Budiningsih [9] "Learning is a process of forming 10 knowledge, in which students actively carry out activities, actively think, formulate concepts, and give meaning to things being studied."

Similar to learning, teaching is essentially a process, namely the process of regulating, organizing the environment around students, so that it can grow and encourage students to carry out the learning process. In the next stage of teaching is the process of providing guidance / assistance to students in carrying out the learning process Sudjana [9]. Meanwhile, learning according to Sadiman, Arief $S$ [9] learning is a complex process that occurs to everyone and lasts a lifetime, from when he was a baby to his grave. One of the signs that someone has learned is a change in behavior in him. Changes in behavior involve both changes in knowledge (cognitive) and skills (psychomotor) and those concerning values and attitudes (affective).

\section{B. Ability to Diagnose Student Difficulties in Learning}

According to Ahmadi in Nurrita learning, [8] says that "in a situation where students cannot learn properly, that is called learning difficulties". Meanwhile, according to Syaiful Bahri Djamarah [10] learning difficulties are "a condition in which students cannot learn naturally, due to threats, obstacles or disruptions in learning". Furthermore Gozali in Learning Psychology, [10], said that "learning difficulties are difficulties in getting the desired behavior change even though the exercises have been carried out. Sasmita [10] says that learning difficulties can be interpreted as a condition.

According to in the learning process which is marked by certain obstacles to obtaining learning outcomes. The obstacles that arise may be realized and may not be realized by the person experiencing them and they can be psychological, sociological or physiological in the whole learning process. Students who experience learning difficulties will experience obstacles in the process of achieving their learning outcomes, so that the achievements they achieve are below what they should or their abilities.

Supervision activities have forced teachers in SDN 263 Rancaloa to open literature related to learning difficulties in children. Because not all children have the same abilities. Some of the efforts made by teachers to make learning activities satisfying students are arranging student seats. Because children who have hearing and vision difficulties should take the front seat position. In addition, the teachers used the media and teaching aids. The use of teaching aids and learning media would be sufficient to help students who have difficulty receiving subject matter. For example, because the subject matter is abstract so that it is difficult for students to understand, a comfortable and joyful learning atmosphere will help students who experience obstacles in receiving subject matter.
The purpose of diagnosing students' difficulties in learning to improve and correct matters concerning learning is deemed not fulfilling the expectations of learning outcomes besides playing a role in a more efficient and more effective use of time in the sense of accelerating the learning process both in terms of time and material.

\section{Creativity in Developing Learning Methods}

Drevdahl [5] creativity is the ability to produce new compositions and ideas that can take the form of imaginative and sentimental activities that may involve the formation of bar patterns and combinations of past experiences associated with existing ones in the present situation. It was emphasized by Guilford that creativity refers to abilities that mark the characteristics of a creative person. The learning method is used to create an active classroom atmosphere. Learning will be boring for teachers, not creative. Creating an active learning atmosphere is the task of the teacher.

According to, Hasby Ashidiqi in Nurril Azizah [7] the learning method is a set of methods used to achieve certain goals in the learning process. Reaffirmed according to Abdurrahman Ginting in Nurril Azizah [7], the learning method is a unique way or pattern of utilizing various basic principles of education as well as various techniques and other related resources so that the learning process occurs in students.

There was something interesting in the supervision activities carried out by the class $5 \mathrm{D}$ teacher (Eva Kusumawati) in giving Indonesian lessons, she made a video recording containing a story to introduce the types of paragraphs, then the students concluded the type of paragraph in question. After answering, there was a difference of opinion among students so that the atmosphere of the discussion was more varied. It is proven that based on the results of learning evaluations who get a score of more than 80 there are more than $50 \%$ by exploring various learning methods, teachers understand the needs of children in class, children will be more interested and feel more comfortable in participating in the learning and teaching process. Also helps children so they don't get bored quickly. In addition to increasing enthusiasm for learning, the use of learning models or methods also makes the learning process more effective. Based on the results of interviews with ten respondents, every time there was a supervision activity, the respondents designed learning methods not only based on textbooks but the respondents were mor happy to adopt from you tube etc. because they were considered more interactive, interesting in conveying and implementing learning methods. SDN 263 Rancaloa environment develops learning methods, they take different ways. The methods they take are, first, dissemination in the sub-district environment. Second, reading books on relevant learning methods. Third, by discussing and exchanging ideas and experiences with fellow teachers at school. With these three ways, according to the teachers, it is an effective way to develop and enrich insights about teaching methods. The majority of respondents also used combination, mixed, 
combined or eclectic methods. In addition, the methods they use are lectures, demonstrations, discussions, assignments, questions and answers, practicum, experiments, problem solving, and so on.

\section{Creativity in Planning, Implementing, and Evaluating, Learning in Developing Professionalism as a Teacher}

The teacher's creativity in planning, implementing, and evaluating learning has been contained in a container called the Learning Implementation Plan (RPP). Learning planning plays an important role in guiding teachers to carry out their professional duties as educators in serving the learning needs of their students. Learning planning is also intended as a first step before the learning process takes place. In carrying out the learning planning there are also problems faced by teachers and students. The lesson plan (RPP) is a plan that describes the procedures and organization of learning to achieve a basic competency set out in the Content Standards and outlined in the syllabus in Dewey, Kunandar [11].

In this case, Gaffar [12] emphasizes that planning can be defined as the process of preparing various decisions that will be carried out in the future to achieve specified goals. Meanwhile, Bagart and Trully in Saripah [12] argued that planning is the beginning of all rational processes, and contains optimism based on the belief that it can solve various problems. In the context of learning planning can be interpreted as the process of compiling subject matter, using teaching media, using teaching approaches or methods, in an allocation of time to be implemented in the next semester to achieve specified goals. The form of cooperation in planning is to involve school personnel. Hoyles [11] argues that it is very necessary for all teachers and other personnel with an interest in school goals to be involved in planning, therefore the school community is responsible for planning that has determined the ability of teachers to develop creativity in planning, implementing, and evaluating learning can be seen from the packaging. RPP, the implementation of learning in the field at SDN 263 Rancaloa itself the preparation of RPP or Lesson Plan is carried out once a week in a container called a class KKG. The objectives of preparing the lesson plan are to: (1) simplify, expedite and improve the results of the teachinglearning process; (2) by compiling a professional, systematic and efficient learning plan, the teacher will be able to see, observe, analyze, and predict learning programs as a logical and planned framework in Rofiqoh, Kunandar [11]. The efforts made in developing the Learning Implementation Plan include holding teacher working group activities whose activities consist of developing a syllabus Trianto in Dewey [13] Assessing Competency Standards and Basic Competencies. Assessing SK and KD of subjects as listed in Content Standards, Identifying Main / Learning Materials. Identify the main material / learning that supports the achievement of KD. Developing Learning Activities. Learning activities are designed to provide learning experiences that involve mental and physical processes in order to achieve basic competency. Formulating Competency Achievement Indicators. Indicators are markers of KD achievement.
Indicators are used as a basis for developing assessment tools. Determining the Type of Assessment. Assessment of the achievement of students' basic competencies is carried out based on indicators. The assessment is carried out by using a test in written form. Determining Time Allocation. Determination of time allocation for each KD is based on the number of effective weeks and the allocation of time for subjects per week. Time allocation is an estimate of the average time to master the basic competencies needed by various students. Determining Learning Resources. Determination of learning resources is based on $\mathrm{SK}$ and $\mathrm{KD}$ as well as main / learning materials, learning activities, and indicators of competency achievement.

The function of the learning plan is as a reference for teachers to carry out teaching and learning activities (learning activities) so that they are more focused and run effectively and efficiently Kusnandar [11].

Teachers in SDN 263 have traced the principle of independent learning introduced by the Minister of Education and Culture, Nadiem Makarim, namely the writing of RPPs (Lesson Plan) is done efficiently and effectively with the aim of making teachers have time to prepare, evaluate the learning process itself.

The RPP (Lesson Plan) arrangement based on independent learning is:

- Writing Subject Identity, which includes: school; subjects; theme; class / semester; Time Allocation.

- Formulating Learning Objectives. Learning objectives describe the process and learning outcomes that are expected to be achieved by students in accordance with basic competencies. Learning objectives are made based on the Competency Standard (SK), (Basic Competencies) $\mathrm{KD}$, and indicators that have been determined.

\section{CONCLUSION}

The implementation of supervision activities for teachers can improve the quality of teachers by developing learning and teaching situations in the classroom, meaning that teachers are given the freedom to choose learning models that are considered fun, effective, leaving an impression on their students but still referring to the established competency and basic competency standards. In diagnosing student difficulties in learning, teachers are required to force teachers in SDN 263 Rancaloa to open literature related to learning difficulties in children. Because not all children have the same abilities. Some of the efforts made by teachers to make learning activities satisfying students are arranging student seats. Because children who have hearing and vision difficulties should take the front seat position. In addition, the teachers used the media and teaching aids. The use of teaching aids and learning media would be sufficient to help students who have difficulty receiving subject matter. Creativity in developing learning methods in the SDN 263 Rancaloa environment develops 
learning methods, they take different ways. The methods they take are, first, dissemination in the sub-district environment. Second, reading books on relevant learning methods. Third, by discussing and exchanging ideas and experiences with fellow teachers at school. With these three ways, according to the teachers, it is an effective way to develop and enrich insights about teaching methods. Creativity in planning, implementing, and evaluating learning in developing professionalism as a teacher in SDN 263, one of the efforts is to hold Teacher Working Group (KKG) activities whose activities contain syllabus surgery, namely reviewing Competency Standards and Basic Competencies. Assessing Competency standards (SK) and KD (Basic Competencies) of subjects as listed in Content Standards, Identifying Main / Learning Materials. Identify the main material / learning that supports the achievement of KD (Basic Competencies). Developing Learning Activities. Learning activities are designed to provide learning experiences that involve mental and physical processes in order to achieve basic competency. Formulating Competency Achievement Indicators. Indicators are markers of $\mathrm{KD}$ achievement. Indicators are used as a basis for developing assessment tools. Determining the Type of Assessment. Assessment of the achievement of students' basic competencies is carried out based on indicators. The assessment is carried out by using a test in written form. Determining Time Allocation. Determination of time allocation for each Competency Standards (KD) is based on the number of effective weeks and the allocation of time for subjects per week. Time allocation is an estimate of the average time to master the basic competencies needed by various students. Determining Learning Resources. Determination of learning resources is based on (Competency standards) SK and (Basic Competencies) $\mathrm{KD}$ as well as main / learning materials, learning activities, and indicators of competency achievement.

Based on the conclusions of the research results, several implications can be conveyed as follows:

- Based on the results of the research further strengthens the theory which states that there is an effect of academic supervision in developing learning and teaching situations in the classroom, the ability to diagnose student difficulties in learning, creativity in developing learning methods, creativity in planning, implementing, and evaluating learning in developing professionalism as a teachers, so based on this research it can be taken into consideration for the principal to improve the implementation of teacher supervision to improve teacher professionalism in teaching.

- For researchers who will conduct research on the effect of supervision on improving teaching and learning and its effects on student learning in the classroom, the results of this study can be used as a reference and a source of theory that can be used as supporting material in the research.

Based on the research results that have been obtained, recommendations can be given which are expected to be useful as follows:

- Teachers are educators who are the key to the success of their students in classroom learning activities, there must be a desire to learn about learning innovations so that they can personally improve their professionalism as a teacher and achieve educational goals properly.

- For further researchers, it is hoped that they will be able to dig deeper into a broad and in-depth picture of the effect of academic supervision in developing learning and teaching situations in the classroom, the ability to diagnose student difficulties in learning, creativity in developing learning methods, creativity in planning, implementing, and evaluating learning in developing professionalism as a teacher.

\section{REFERENCES}

[1] Dalawi, et al., Pelaksanaan Supervisi Akademik Pengawas Sekolah Sebagai Upaya Peningkatan Profesionalisme Guru SMP Negeri 1 Bengkayang. 2015. [Online] Available at https://www.neliti.com/id/publications/214839/pelaksanaan-supervisiakademik-pengawas-sekolah-sebagai-upaya-peningkatan-profes

[2] Manullang, Dasar_Dasar Manajemen, Gadjah Mada University Press. 2005

[3] Permendiknas 41 no 7. 2019. Lampiran Peraturan Menteri Pendidikan Nasional (Permendiknas) Nomor 41 Tahun 2007 tentang Standar Proses untuk Satuan Pendidikan Dasar dan Menengah.

[4] Permendiknas. Lampiran Peraturan Menteri Pendidikan Nasional (Permendiknas) Supervisi dan Evaluasi.

[5] M. Messi, W. Anggita Sari, W. Anggita Sari, M. Murniyati, and M Murniyati, "Pelaksanaan Supervisi Akademik Pengawas Sekolah Sebagai Upaya Peningkatan Profesionalisme Guru”. JMKSP (Jurnal Manajemen, Kepemimpinan, Dan Supervisi Pendidikan). 2018

[6] S. Arikunto, Supervisi Pendidikan. 2002

[7] N. Azizah, Pengertian Metode Pembelajaran. 2019. [Online] Available at: https://id.scribd.com/document/435466326/Makalah-TEORI

[8] T. Nurrita, Pengembangan Media Pembelajaran Untuk Meningkatkan Hasil Belajar Siswa. 2018. [Online] Available at: pengembangan-mediapembelajaran-untuk-me-b2104bd7.pdf

[9] Aunurrahman, Belajar dan Pembelajaran, Bandung: Alfabeta, 2013.

[10] A.F. Huda, Psikologi Belajar. Pengertian Kesulitan Belajar. 2018. [Online] Available at: http://fatkhan.web.id/pengertian-kesulitan-belajar/

[11] F.H. Rofiqoh et al., Merencanakan Dan Melaksanakan Pembelajaran. 2016. [Online] Available at: http://pendekatanbelajarjokoblog.blogspot.com/2016/11/merencanakandan-melaksanakan.html

[12] I. Saripah, Konsep Perencanaan. n.d. [Online] Available at: http://digilib.unimed.ac.id/681/1/Perencanaan.

[13] D. John, Silabus dan RPP: Pengertian, Tujuan, Manfaat, Pedoman, Prinsip, Pengembangan. Gramedia. n.d. 